\title{
Acupressure and ondansetron for postoperative nausea and vomiting after laparoscopic cholecystectomy
}

\author{
[L'acupression et l'ondansétron contre les nausées et les vomissements suivant la \\ cholécystectomie laparoscopique]
}

Anil Agarwal MD, * Neeta Bose MD, ${ }^{*}$ Atul Gaur MD, * Uttam Singh PhD, † Mithlesh Kumar Gupta MD, Dinesh Singh MD*

Purpose: To compare the efficacy of acupressure wrist bands and ondansetron for the prevention of postoperative nausea and vomiting (PONV).

Methods: One hundred and fifty ASA I-II, patients undergoing elective laparoscopic cholecystectomy were included in a randomized, prospective, double-blind and placebo-controlled study. Patients were divided into three groups of 50. Group I was the control; Group II received ondansetron 4 mg iv just prior to induction of anesthesia; in Group III acupressure wristbands were applied at the P6 points. Acupressure wrist bands were placed inappropriately in Groups I and II. The acupressure wrist bands were applied 30 min prior to induction of anesthesia and removed six hours following surgery. Anesthesia was standardized. PONV were evaluated separately as none, mild, moderate or severe within six hours of patients' arrival in the postanesthesia care unit and then at $24 \mathrm{hr}$ after surgery by a blinded observer. If patients vomited more than once, they were given $4 \mathrm{mg}$ ondansetron iv as the rescue antiemetic. Results were analyzed by $Z$ test. $A P$ value of $<0.05$ was taken as significant.

Results: The incidence of PONV and the requirement of rescue medication were significantly lower in both the acupressure and ondansetron groups during the first six hours.

Conclusion: Acupressure at P6 causes a significant reduction in the incidence of PONV and the requirement for rescue medication in the first six hours following laparoscopic cholecystectomy, similar to that of ondansetron $4 \mathrm{mg}$ iv.
Objectif : Comparer l'efficacité des bandes d'acupression et de l'ondansétron comme prévention des nausées et vomissements postopératoires (NVPO).

Méthode : Cent cinquante patients d'état physique ASA I-II devant subir une cholécystectomie laparoscopique ont été recrutés pour une étude prospective, randomisée et à double insu contre placebo. Ils ont été répartis en trois groupes de 50. Le groupe l a été le groupe témoin; les patients du groupe II ont reçu 4 mg iv d'ondansétron juste avant l'induction de l'anesthésie; chez les patients du groupe III, on a appliqué des bandes d'acupression aux point P6. Des bandes d'acupression ont été placées de façon inappropriée chez les patients des groupes I et II. Les bandes ont été appliquées 30 min avant l'induction et enlevées six heures après l'opération. L'anesthésie a été normalisée. Les NVPO ont été évalués séparément comme inexistants, légers, modérés ou sévères pendant les six premières heures en salle de réveil, puis 24 h après l'opération par un observateur impartial. Si les patients vomissaient plus d'une fois, ils recevaient $4 \mathrm{mg}$ d'ondansétron iv comme antiémétique de secours. Les résultats ont été analysés avec le test $Z$. Une valeur de $P<0,05$ était considérée significative.

Résultats : L'incidence de NVPO et les besoins de médication de secours ont été significativement plus faibles autant avec l'acupression qu'avec l'ondansétron pendant les six premières heures.

Conclusion : L'acupression en P6 réduit de façon significative l'incidence de NVPO et la nécessité d'antiémétique de secours pendant les six premières heures suivant la cholécystectomie laparoscopique. Son effet est donc similaire à celui de 4 mg iv d'ondansétron.

From the Department of Anesthesia, ${ }^{*}$ and Biostatistics, $†$ Sanjay Gandhi Postgraduate Institute of Medical Sciences, Lucknow, India. Address correspondence to: Dr. Anil Agarwal, Type IV / 48, S.G.P.G.I.M.S., Lucknow, 226 014, India. Phone: +91-522-440004-8, ext. 2473(O), 2474(R); Fax: +91-522-440017, 440047, 440078; E-mail: aagarwal@sgpgi.ac.in Accepted for publication January 23, 2002.

Revision accepted March 15, 2002. 
$\mathrm{P}$ OSTOPERATIVE nausea and vomiting (PONV) is frequent in patients undergoing general anesthesia. This is a distressing experience for patients. When symptoms persist, they may lead to dehydration, electrolyte imbalance and delayed hospital discharge. This may have significant implications regarding cost of therapy especially in day stay surgery. More serious complications may ensue, including tension on suture lines, venous hypertension and increased bleeding under skin flaps affecting quality of surgical outcome. The patients are at increased risk of pulmonary aspiration of vomitus as the airway reflexes are depressed postoperatively. ${ }^{1}$

The incidence of PONV may be as high as $60-70 \%$, and is influenced by various patient related factors, type of surgery, anesthesia technique and drugs used and postoperative factors such as pain, dizziness, ambulation, usage of opiods etc. ${ }^{1,2-5}$ Laparoscopic cholecystectomy predisposes the patient to several stimuli which can induce vomiting. Various pharmacological means are available to alleviate PONV, but may cause side effects varying from lethargy, restlessness, tachycardia, extrapyramidal symptoms, dystonic reactions increasing the incidence of delayed discharge and unintended hospital re-admissions.

Acupuncture and acupressure are methods used by alternative medicine with varying results for the treatment of nausea and vomiting due to morning sickness, ${ }^{6}$ chemotherapy, ${ }^{7}$ general anesthesia, ${ }^{8}$ and postoperative morphine administration. ${ }^{9}$ Acupuncture and acupressure are based on the belief that an individual's well being depends on the balance of energy in the body. It is hypothesized that energy flows within the body along paths referred to as meridians and these techniques restore the balance of energy by manipulating these meridians. ${ }^{10}$ P6 (Nei-guan) a Chinese meridian point is used for the treatment of nausea and vomiting. The present study was aimed at comparing the effectiveness of acupressure wrist bands with ondansetron in preventing PONV in patients undergoing laparoscopic cholecystectomy.

\section{Methods}

Following approval from our institutional Research Committee and Ethical Clearance, informed consent was obtained from all patients included in this study. One hundred and fifty patients of either sex, aged between 18 and $60 \mathrm{yr}$, ASA grade I-II, undergoing laparoscopic cholecystectomy were included in this randomized, prospective, double-blind and placebocontrolled study. Patients were randomized into three groups of 50 each using a table of random numbers:

\author{
Group I - Control \\ Group II - Ondansetron \\ Group III - Acupressure
}

In Groups I and II, the spherical beads of the acupressure wrist bands were placed inappropriately on the posterior surface of both forearms $30 \mathrm{~min}$ prior to induction of anesthesia. Group II patients received ondansetron $4 \mathrm{mg} i v$ just before induction. In Group III patients' acupressure bands were applied at the P6 point on both forearms $30 \mathrm{~min}$ before induction of anesthesia. Groups I and III patients received normal saline $1 \mathrm{~mL}$ iv just before induction of anesthesia to maintain blinding.

The acupressure wrist band has an adjustable strap $1.5 \mathrm{~cm}$ in width, a spherical plastic bead and a Velcro fastener to hold the bead in position (Figure 1). The treatment point P6 (Nei-Guan) is located on the anterior surface of the forearm approximately $\mathrm{l} \mathrm{cm}$ deep to the skin, 2 body inches proximal to the distal crease of the wrist joint between the two tendons of flexor carpi radialis and palmaris longus. One body inch is equal to the width of the interphalangeal joint of the patient's thumb. The acupressure band was placed around the wrist, such that patient felt gentle pressure without discomfort. To confirm that compression was not excessive, a pulse oximeter was placed on the index finger to confirm adequate blood flow. Wrist bands were considered too loose and were tightened if a wedge of paper could fit between the pressure band and skin. Forearms were raised by 60 at the elbow and venous emptying occurred normally in all cases.

Exclusion criteria included patient's refusal to participate in the study, previous history of PONV and travel sickness, impaired renal function with increased urea and creatinine concentrations, diabetes mellitus, obesity, patients receiving antiemetic medication or a histamine $\mathrm{H}_{2}$-receptor antagonist within $72 \mathrm{hr}$ of surgery.

Anesthesia was standardized. No antiemetic medication was given before or during the operation. All patients received $2 \mathrm{mg}$ lorazepam po the night before surgery and two hours prior to surgery with sips of water. Anesthesia was induced with $2 \mu \mathrm{g} \cdot \mathrm{kg}^{-1}$ fentanyl $i$ p and $4-5 \mathrm{mg} \cdot \mathrm{kg}^{-1}$ thiopentone and maintained with isoflurane $0-1 \%$ and nitrous oxide $60 \%$ in oxygen. Neuromuscular block was provided by vecuronium. At the end of the surgical procedure patients were extubated in the operating room after reversal of the neuromuscular block with neostigmine and atropine. Postoperative analgesia was provided with $100 \mathrm{mg}$ diclofenac im every eight hours. The acupressure wrist band was removed six hours postoperatively.

The incidence of PONV was evaluated within six hours of the patient's arrival in the postanesthesia care 
TABLE I Demographic data and duration of surgery

\begin{tabular}{|c|c|c|c|c|c|}
\hline Groups & Age (yr) & $\operatorname{Sex}(M / F)$ & Weight (kg) & Height $(\mathrm{cm})$ & $\begin{array}{l}\text { Duration of } \\
\text { surgery (min) }\end{array}$ \\
\hline I (Control) & $40.2 \pm 9.9$ & $18 / 32$ & $56 \pm 11$ & $159 \pm 6$ & $96 \pm 30$ \\
\hline II (Ondansetron) & $41.4 \pm 12.3$ & $15 / 35$ & $59 \pm 10$ & $157 \pm 7$ & $88 \pm 33$ \\
\hline III (Acupressure) & $39.2 \pm 10.4$ & $16 / 34$ & $63 \pm 9$ & $160 \pm 5$ & $90 \pm 27$ \\
\hline
\end{tabular}

Values are mean $\pm \mathrm{SD}$; test $=$ three samples assuming equal variance.

TABLE II Incidence of nausea / vomiting / requirement of rescue antiemetics within six hours and between six to 24 hr following laparoscopic cholecystectomy

\begin{tabular}{llcccc}
\hline $\begin{array}{l}\text { Groups } \\
(n=50)\end{array}$ & $6 \mathrm{hr}$ & $6-24 \mathrm{hr}$ & \multicolumn{2}{c}{ Vomiting } & Rescue antiemetics \\
$6-24 \mathrm{hr}$ & $6 \mathrm{hr}$ & $6-24 \mathrm{hr}$ & 0 \\
\hline I (Control) & $12^{*}$ & 6 & $10^{*}$ & 3 & $4^{*}$ \\
II (Ondansetron) & 2 & 2 & 2 & 0 & 0 \\
III (Acupressure) & 3 & 2 & 2 & 0 & 0 \\
\hline
\end{tabular}

* Denotes $P<0.05$.

TABLE III Severity of nausea / vomiting within six hours following laparoscopic cholecystectomy

\begin{tabular}{|c|c|c|c|c|c|}
\hline \multirow{2}{*}{$\begin{array}{l}\text { Groups } \\
(n=50)\end{array}$} & \multirow[t]{2}{*}{$I$ (Control) } & \multirow[t]{2}{*}{ II (Ondansetron) } & \multirow[t]{2}{*}{ III (Acupressure) } & \multicolumn{2}{|c|}{ Power of statistical test } \\
\hline & & & & $\begin{array}{l}\text { Control vs } \\
\text { ondansetron }\end{array}$ & $\begin{array}{l}\text { Control vs } \\
\text { acupressure }\end{array}$ \\
\hline \multicolumn{6}{|l|}{ Nausea } \\
\hline None & 38 & 48 & 47 & & \\
\hline $\operatorname{Mild}(\mathrm{A})$ & 6 & 2 & 2 & & \\
\hline Moderate (B) & 4 & 0 & 1 & & \\
\hline Severe $(\mathrm{C})$ & 2 & 0 & 0 & & \\
\hline $\begin{array}{l}\text { Nausea } \\
(A+B+C)\end{array}$ & $12^{*}$ & 2 & 3 & 87 & 75 \\
\hline \multicolumn{6}{|l|}{ Vomiting } \\
\hline None & 40 & 48 & 48 & & \\
\hline Mild (A) & 10 & 2 & 2 & & \\
\hline Moderate (B) & 0 & 0 & 0 & & \\
\hline Severe $(\mathrm{C})$ & 0 & 0 & 0 & & \\
\hline $\begin{array}{l}\text { Vomiting } \\
(\mathrm{A}+\mathrm{B}+\mathrm{C})\end{array}$ & $10^{*}$ & 2 & 2 & 75 & 75 \\
\hline Antiemetic & $4^{*}$ & 0 & 0 & 81 & 81 \\
\hline
\end{tabular}

* Denotes $P<0.05$.

unit and then at $24 \mathrm{hr}$ after surgery by a blinded observer. The results were scored as none, nausea, retching/vomiting. Patients experiencing both nausea and vomiting were included in the vomiting group. ${ }^{11}$ Nausea was graded by visual analogue scale from 1-10 (1 = none, $2-5=$ mild, $6-7=$ moderate and $8-10=$ severe $)$. Vomiting and retching were not distinguished and their severity was classified using the number of episodes over 24 hr i.e., none, mild (0-2), moderate (3-5), or severe $(>5) .{ }^{12}$ If patients vomited more than once, they were given $4 \mathrm{mg}$ ondansetron $i v$ as the rescue antiemetic.

Patients' characteristics in the three groups were assessed using an unpaired Student's t test. PONV data was analyzed using a $\mathrm{Z}$ test to compare the occurrence in all three groups. Comparisons between groups were performed for overall nausea and retching/vomiting. Nausea and retching/vomiting were then compared separately at various levels of severity. A $P$ value of $<0.05$ was considered significant.

\section{Results}

Patients were comparable in all three groups with regard to age, sex, height, weight and duration of surgery (Table I).

The incidence of PONV in the first six hours after laparoscopic cholecystectomy in the control group 


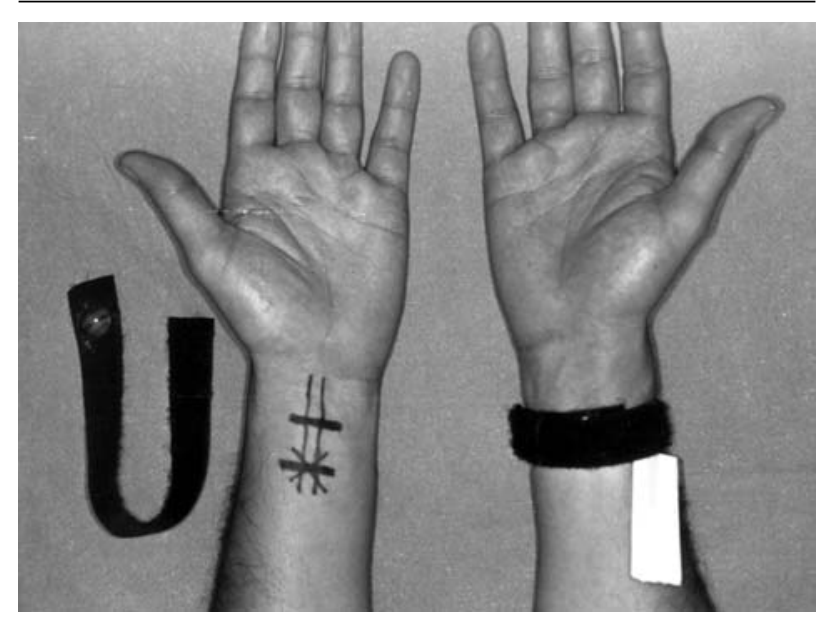

FIGURE 1 Location of P6 meridian point and the proper application of the acupressure wristband (see methods for details)

was $44 \%$. The acupressure and ondansetron groups had a significant decrease in the incidence of PONV during the same period ( $10 \%$ and $8 \%$ respectively). There was no significant difference in PONV in the six to $24 \mathrm{hr}$ following laparoscopic cholecystectomy surgery in all three groups (Figure 2, Tables II and III). A significant decrease in the requirement for rescue medication in groups II and III was observed in the first six hours following surgery. Antiemetic requirements were similar in the three groups at $24 \mathrm{hr}$ following surgery (Tables II and III). No side effects or complications were observed due to the placement of acupressure wrist bands.

\section{Discussion}

Laparoscopic cholecystectomy for the treatment of cholelithiasis is popular amongst surgeons as well as patients due to its associated advantages, which includes a short hospital stay. The latter advantage has been negated by PONV, which is turning out to be the leading cause of unexpected re-admission after day surgery. ${ }^{13,14}$ The incidence of PONV has been reported to be as high as $53-72 \%{ }^{15}$ After laparoscopic cholecystectomy up to $70 \%$ patients have PONV if they are not on any antiemetic prophylaxis. ${ }^{16-18}$

The etiology of PONV after laparoscopic cholecystectomy is not wholly understood. Risk factors such as a prolonged $\mathrm{CO}_{2}$ insufflation, gall bladder surgery, intraoperative use of isoflurane, fentanyl and glycopyrrolate, female sex and postoperative use of patient controlled analgesia with morphine may contribute to these episodes. . $15,17,19,20 \mathrm{CO}_{2}$ insufflation significantly

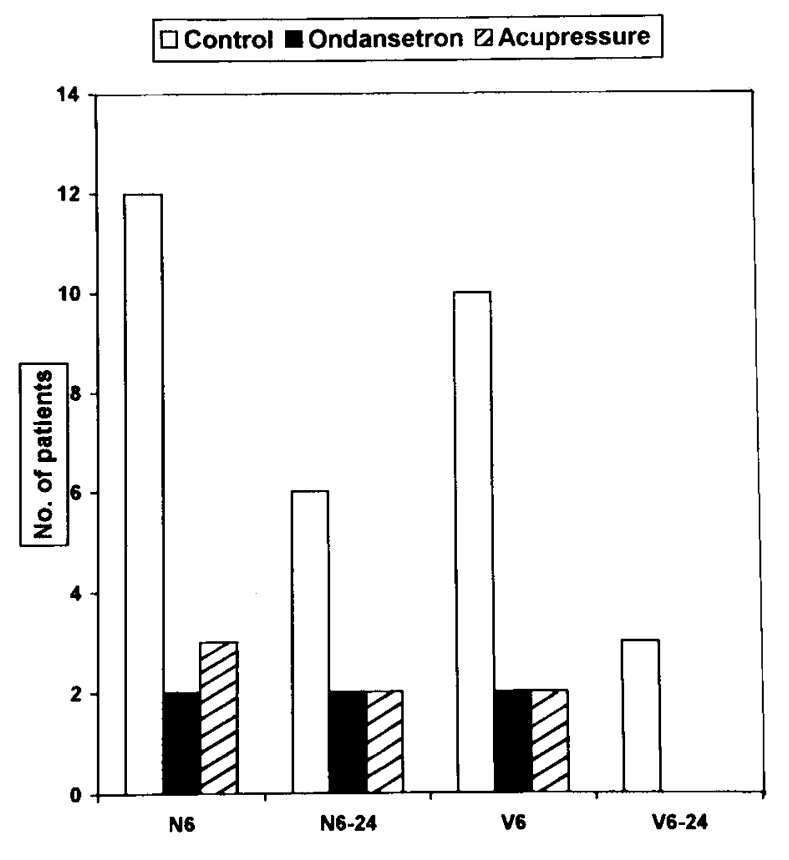

FIGURE 2 Number of patients presenting with nausea or vomiting during the first six hours (N6 and V6) and from 6-24 hr (N624 and V6-24) respectively after laparoscopic cholecystectomy.

increases peritoneal pressure, reduces intestinal blood flow and leads to intestinal ischemia and release of emetogenic substances. ${ }^{14}$ Also, the emetic centre is stimulated by the afferents from the gastro-intestinal track manipulated during surgery. ${ }^{1}$ Intraoperative hypotension may cause brainstem hypoxia and thus trigger the vomiting centre to induce emesis. ${ }^{21}$ Further, the intestinal tissue is active metabolically and has a poor tolerance for even brief periods of hypoxia/ischemia. An important intestinal response to ischemia is the release of serotonin, a highly emetogenic substance.

There are various drug therapies for the prevention of PONV. Droperidol is an effective antiemetic, but is associated with side effects such as agitation, sedation, extra-pyramidal reactions and delayed awakening with large doses. Smaller doses of $(0.625 \mathrm{mg})$ of droperidol are as effective as larger doses $(1.25 \mathrm{mg})$ and $4 \mathrm{mg}$ iv ondansetron. Lower doses of droperidol may also be associated with restlessness. ${ }^{18}$ Transdermal scopolamine decreases PONV after laparoscopic surgeries, but $91 \%$ of patients experience side effects. ${ }^{13,22}$ Phenothiazines and antihistamines can produce sedation and lethargy. Metoclopramide is also an effective antiemetic but not without side effects including dystonic reactions, rest- 
lessness and tachycardia. Symptoms resembling parkinsonism have also been reported in children. ${ }^{23}$ Antagonists at the $\mathrm{NK}_{1}$ receptor represent a new class of antiemetics, which is still under investigation. ${ }^{24}$

Ondansetron, a 5-hydroxy tryptamine subtype 3 (5HT3) receptor antagonist, is an effective antiemetic for the prevention and treatment of PONV. ${ }^{1,13}$ It has been extremely useful in reducing PONV in women undergoing ambulatory gynecologic laparoscopic procedures. Despite its advantages, including minimal side effects, it is expensive compared with other antiemetics and may consume a major portion of an anesthetic pharmacy budget. ${ }^{18,25}$

Non-pharmacological methods like acupuncture, acupressure and laser stimulation have shown comparable antiemetic efficacy. ${ }^{26}$ The P6 (Nei-Guan) meridian point in acupuncture has been used to treat vomiting and other stomach ailments in traditional Chinese medical practice. In 1990, Dundee showed that acupuncture or acupressure at the P6 meridian point was as effective as a standard antiemetic in the treatment of nausea and vomiting. ${ }^{27}$

The mechanism of action of acupressure is not clear. It is postulated that acupressure causes low frequency electrical stimulation of the skin sensory receptors which may activate $A B$ and $A \delta$ fibres. These fibres synapse within the dorsal horn and may, in turn, cause release of endorphins from the hypothalamus. Increased levels of $B$-endorphin concentration have been reported in human cerebrospinal fluid after acupuncture stimulation. ${ }^{21,28}$ In addition, serotonergic and norepinerphrinergic fibres may be activated and a possible change in serotonin levels has a role in prevention of PONV. It is also postulated that opiods may have antiemetic effects mediated by the action of $\beta$-endorphins on $\mu$ receptors. Acupressure has been shown to enhance gastric motility. ${ }^{29}$ There is also a possible role of central dopaminergic receptors in acupuncture. The antiemetic effect of the P6 point may be mediated by an action opposing to that of central dopamine. ${ }^{30}$

Acupuncture and acupressure at the P6 point is associated with mixed clinical results. Harmon, ${ }^{4}$ Stein, ${ }^{21}$ Fan, ${ }^{31}$ and Dundee ${ }^{27,32,33}$ have observed a decrease in the incidence of PONV after P6 stimulation. The important component of this treatment includes the timing of stimulation ${ }^{31,34}$ and correct point location. ${ }^{31,35}$ For acupressure to be effective, it has to be applied prior to the emetic stimulus. A meta analysis was conducted to assess the efficacy of nonpharmacological techniques such as acupuncture, electro-acupuncture, transcutaneous electrical nerve stimulation, acupoint stimulation and acupressure for the prevention of PONV. ${ }^{36}$ Non-pharmacological techniques were more effective in comparison to placebo for the prevention of PONV within six hours of surgery in adults. ${ }^{36}$ However, P6 stimulation was ineffective in minimizing PONV in children following tonsillectomy and strabismus surgery. ${ }^{37-39}$ Similarly, acupressure has been ineffective in cases of urological endoscopic surgery and pregnancy. ${ }^{40,41}$

In summary we compared acupressure with ondansetron and placebo for the prevention of PONV in adult patients undergoing laparoscopic cholecystectomy. We observed that the incidence of PONV and the requirement for rescue antiemetics were significantly lower in the acupressure and ondansetron groups in the first six hours following laparoscopic cholecystectomy. However, there was no significant difference in PONV and the antiemetics required at $24 \mathrm{hr}$ following laparoscopic cholecystectomy in all three groups.

\section{References}

1 Watcha MF, White PF. Postoperative nausea and vomiting. Its etiology, treatment, and prevention.

Anesthesiology 1992; 77: 162-84.

2 Korttila $K$. The study of postoperative nausea and vomiting. Br J Anaesth 1992; 69(Suppl. 1): 20S-3S.

3 Haley $S$, Edelist $G$, Urbach G. Comparison of alfentanil, fentanyl and enflurane as supplements to general anaesthesia for outpatient gynaecologic surgery. Can J Anaesth 1988; 35: 570-5.

4 Harmon D, Gardiner J, Harrison R, Kelly A. Acupressure and the prevention of nausea and vomiting after laparoscopy. Br J Anaesth 1999; 82: 387-90.

5 Watcha MF, Simeon RM, White PF, Stevens JL. Effect of propofol on the incidence of postoperative vomiting after strabismus surgery in pediatric outpatients. Anesthesiology 1991; 75: 204-9.

6 Dundee JW, Sourial FBR, Ghaly RG, Bell PF. P6 acupressure reduces morning sickness. J R Soc Med 1988; 81: 456-7.

7 Dundee JW, Ghaly RG, Fitzpatrick KTJ, Lynch G, Abram P. Optimising antiemesis in cancer chemotherapy (Letter). Br Med J (Clin Res Ed) 1987; 294: 179.

8 Dundee JW, Ghaly RG, Bill KM, Chestnutt WN, Fitzpatrick KTJ, Lynas AGA. Effect of stimulation of the P6 antiemetic point on postoperative nausea and vomiting. Br J Anaesth 1989; 63: 612-8.

9 Ho CM, Hseu SS, Tsai SK, Lee TY. Effect of P-6 acupressure on prevention of nausea and vomiting after epidural morphine for post-cesarean section pain relief. Acta Anaesthesiol Scand 1996; 40: 372-5.

10 Vincent CA, Richardson PH. The evaluation of therapeutic acupuncture: concepts and methods. Pain 1986; 24: 1-13. 
11 Allen DL, Kitching AJ, Nagle C. P6 acupressure and nausea and vomiting after gynaecological surgery. Anaesth Intensive Care 1994; 22: 691-3.

12 Tigerstedt I, Salmela L, Aromaa U. Double-blind comparison of transdermal scopolamine, droperidol and placebo against postoperative nausea and vomiting. Acta Anaesthesiol Scand 1988: 32: 454-7.

13 Liberman $M A$, Howe $S$, Lane $M$. Ondansetron versus placebo for prophylaxis of nausea and vomiting in patients undergoing ambulatory laparoscopic cholecystectomy. Am J Surg 2000; 179: 60-2.

14 Goll V, Akça O, Greif R, et al. Ondansetron is no more effective than supplemental intraoperative oxygen for prevention of postoperative nausea and vomiting. Anesth Analg 2001; 92: 112-7.

15 Wang JJ, Ho ST, Liu $\Upsilon$ H, et al. Dexamethasone reduces nausea and vomiting after laparoscopic cholecystectomy. Br J Anaesth 1999; 83: 772-5.

16 Parlow JL, Meikle AT, van Vlymen J, Avery N. Post discharge nausea and vomiting after ambulatory laparoscopy is not reduced by promethazine prophylaxis. Can J Anesth 1999; 46: 719-24.

17 Naguib M, El Bakry AKE, Khoshim MHB, et al. Prophylactic antiemetic therapy with ondansetron, tropisetron, granisetron and metoclopramide in patients undergoing laparoscopic cholecystectomy: a randomized, double-blind comparison with placebo. Can J Anaesth 1996; 43: 226-31.

18 Tang J, Watcha MF, White PF. A comparison of costs and efficacy of ondansetron and droperidol as prophylactic antiemetic therapy for elective outpatient gynecologic procedures. Anesth Analg 1996; 83: 304-13.

19 Coben MM, Duncan PG, DeBoer DP, Tweed WA. The postoperative interview: assessing risk factors for nausea and vomiting. Anesth Analg 1994; 78: 7-16.

20 Fredman B, Jedeikin R, Olsfanger D, Flor P, Gruzman $A$. Residual pneumoperitoneum: a cause of postoperative pain after laparoscopic cholecystectomy. Anesth Analg 1994; 79: 152-4.

21 Stein DJ, Birnbach DJ, Danzer BI, Kuroda MM, Grunebaum A, Thys DM. Acupressure versus intravenous metoclopramide to prevent nausea and vomiting during spinal anesthesia for cesarean section. Anesth Analg 1997; 84: 342-5.

22 Bailey PL, Streisand JB, Pace NL, et al. Transdermal scopolamine reduces nausea and vomiting after outpatient laparoscopy. Anesthesiology 1990; 72: 977-80.

23 Ferrari LR, Donlon JV. Metoclopramide reduces the incidence of vomiting after tonsillectomy in children. Anesth Analg 1992; 75: 351-4.

24 Heffernan AM, Rowbotham DJ. Postoperative nausea and vomiting - time for balanced antiemesis? (Editorial). Br J Anaesth 2000; 85: 675-7.
25 Kapur PA. Pharmacy acquisition costs: responsible choices versus overutilization of costly pharmaceuticals (Editorial). Anesth Analg 1994; 78: 617-8.

26 White PF. Are nonpharmacologic techniques useful alternatives to antiemetic drugs for the prevention of nausea and vomiting? Anesth Analg 1997; 84: 712-4.

27 Dundee JW. Belfast experience with P6 acupuncture antiemesis. Ulster Med J 1990; 59: 63-70.

28 Clement-Jones V, McLoughlin L, Tomlin S, Besser GM, Rees LH, Wen HL. Increased B-endorphin but not metenkephalin levels in human cerebrospinal fluid after acupuncture for recurrent pain. Lancet 1980; 1 : 946-8.

29 Lin X, Liang J, Ren J, Mu F, Zhang M, Chen JDZ. Electrical stimulation of acupuncture points enhances gastric myoelectrical activity in humans. Am J Gastroenterol 1997; 92: 1527-30.

30 Fassoulaki A, Papilas K, Sarantopoulos C, Zotou M. Transcutaneous electrical nerve stimulation reduces the incidence of vomiting after hysterectomy. Anesth Analg 1993; 76: 1012-4.

31 Fan CF, Tanhui E, Joshi S, Trivedi S, Hong $\Upsilon$, Shevde K. Acupressure treatment for prevention of postoperative nausea and vomiting. Anesth Analg 1997; 84: 821-5.

32 Dundee JW, McMillan CM. Clinical uses of P6 acupuncture antiemesis. Acupunct Electrother Res 1990; 15: 211-5.

33 Dundee JW, Ghaly G. Local anesthesia blocks the antiemetic action of P6 acupuncture. Clin Pharmacol Ther 1991; 50: 78-80.

34 Dundee JW, Ghaly RG. Does the timing of P6 acupuncture influence it's efficacy as a postoperative anti- emetic? Br J Anaesth 1989; 63: 630P.

35 Fitzpatrick KTJ, Dundee JW, Ghaly RG, Patterson CC. Is it necessary always to use the right forearm for acupuncture antiemesis? Br J Anaesth 1988; 61: 117-8P.

36 Lee A, Done $M L$. The use of nonpharmacologic techniques to prevent postoperative nausea and vomiting: a meta-analysis. Anesth Analg 1999; 88: 1362-9.

37 Shenkman Z, Holzman RS, Kim C, et al. Acupressure acupuncture antiemetic prophylaxis in children undergoing tonsillectomy. Anesthesiology 1999; 90: 1311-6.

38 Yentis SM, Bissonnette B. P6 acupuncture and postoperative vomiting after tonsillectomy in children. Br J Anaesth 1991; 67: 779-80.

39 Lewis IH, Pryn SJ, Reynolds PI, Pandit UA, Wilton NCT. Effect of P6 acupressure on postoperative vomiting in children undergoing outpatient strabismus correction. Br J Anaesth 1991; 67: 73-8.

40 Agarwal A, Pathak A, Gaur A. Acupressure wristbands do not prevent postoperative nausea and vomiting after urological endoscopic surgery. Can J Anesth 2000; 47: 319-24. 
41 O'Brien B, Relyea MJ, Taerum T. Efficacy of P6 acupressure in the treatment of nausea and vomiting dur ing pregnancy. Am J Obstet Gynecol 1996; 174: $708-15$.

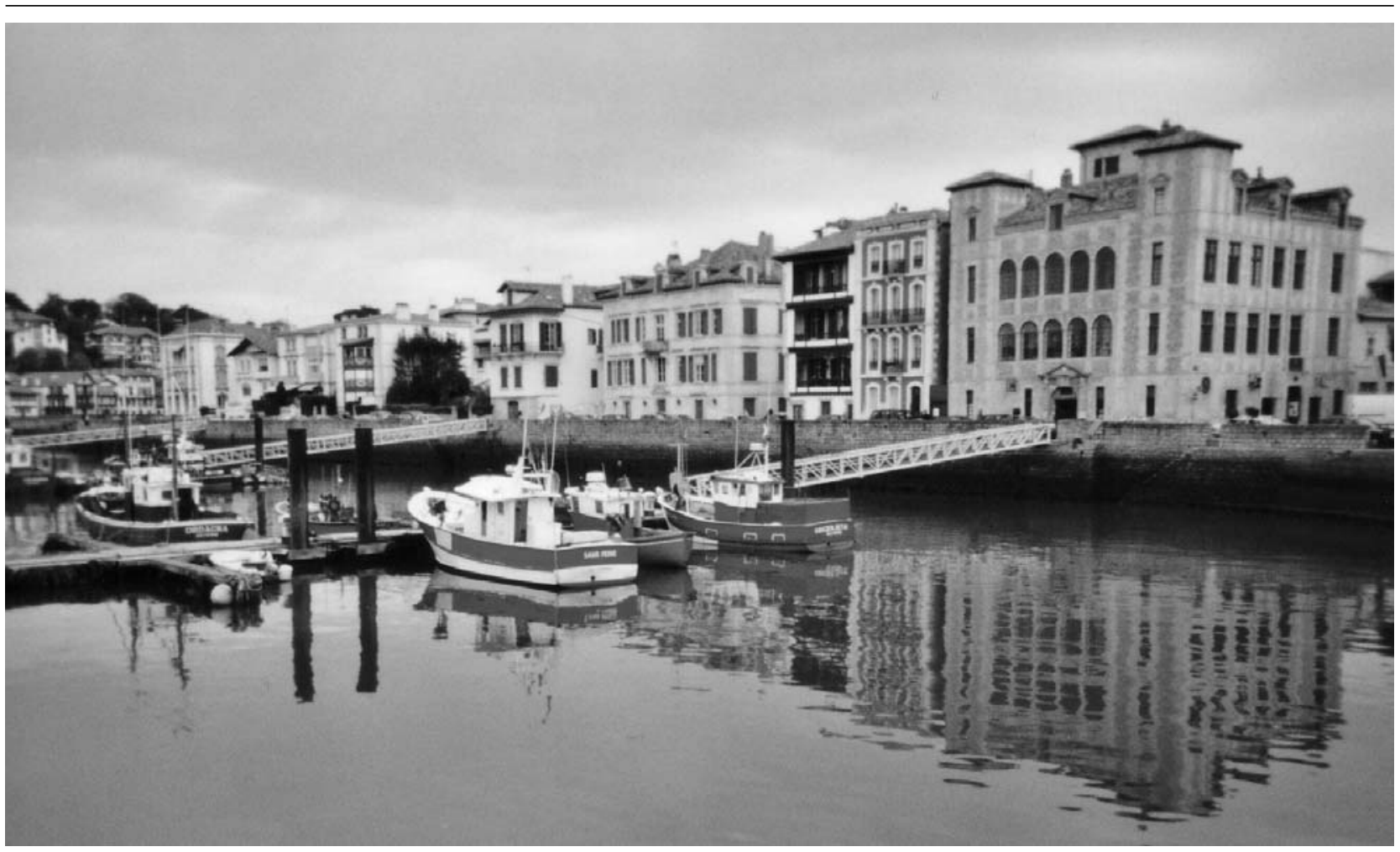

Maison de l'Infante, St Jean de Luz (Pays Basque) - France 